\title{
Burning questions
}

A s a budding health writer I was Avery excited to be attending my first press conference, convened to address avian influenza - such a sizzling topic that the briefing was held at the US embassy in Ottawa.

I had, in a very professional manner, caught a taxi to the embassy. But I arrived early, and tired, and decided to go over the road - across the road, my Canadian colleagues would say - to get a coffee to perk me up. But getting to the coffee shop that stands directly accross the street from the embassy wasn't as easy as "going over the road." The section of Sussex Drive commanded by the embassy has been blocked off as a security measure, and I had to walk a full block down and then back up to the coffee shop.

Ordering the coffee wasn't any easier. "Can I have a take-away coffee please?" Blank look. "Ah, a takeout coffee?" I tried a different tack.

Still blank. "Co-ffee?" I said slowly. I could see the coffee machine, but evidently there was a problem. The waiter suddenly nodded and sent me to the back of the café next to the machine, presumably so I

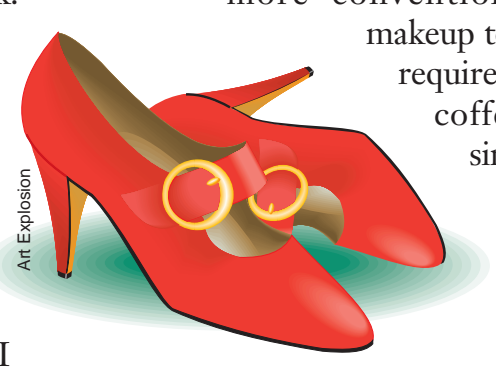
could point more easily. The waitress at the machine smiled. "Can I have a takeaway coffee" I said. Again the blank look. "Takeout?" I tried hopefully. Nothing. "I would like to have a coffee that I can take with me." Ah. Blinding recognition. "You want a coffee to go," she said. Should it really be this hard?

With my now-precious café latte in hand, I headed off for my two-block walk to get to the gate opposite me. By the time I arrived there was a queue of people waiting to get in - suited types, mainly, and one woman journalist wearning a tropical coloured floral not a terrorist. I was al-

knee-length jacket. Having passed through the first metal detector and unloaded mobile phones, car keys (the electronic ones) and other deadly apparatus, we snaked our way between the first heavy glass doors. The security personnel were letting people trickle through in twos, as they needed time to get organized for the next metal detector and bag x-ray.

Finally it was my go. Having watched several rounds already I was prepared: I had my watch off and in the basket in a flash, my bag on the belt. My coffee had to be placed on the table while I passed through the metal detector. The $\mathrm{x}$-ray inspection of my bag revealed the presence of both lipstick and lipliner (it was a big day), both of which I was requested to apply to my person to demonstrate they did not contain a dangerous substance. The guard indicated my forearm as a potential test site; I more conventionally applied the makeup to my lips. I was then required to take a sip of my coffee; it proved to be similarly benign. They take biosecurity very seriously in Ottawa.

It was all going so well. I was lowed to have my tape-recorder, and now all I needed was my coffee. As I went to put the lid back on, my new Lois Lane superreporter strength surpassed me. Pressing down on the coffee lid I managed to squash the whole thing, bending and breaking the polystyrene - um, Styrofoam - cup in two, spraying coffee across the metal detector, the table of personal possessions and the floor.

I wasn't sure what hurt more, my burnt hand or my ego.

The Chief Health Officer of Ottawa (a distinguished chap in a suit) and a pearl-laden red-outfitted woman who were next to me in the queue seemed unimpressed. Not only did they have to wait for the inner air-locked doors to open and their building escort to arrive, they now also had to wait for the coffee to be cleaned up. Ditto for the TV crew waiting on the other side of the glass holding doors.

I slunk in my smart red shoes along the sterile embassy hall, head down, looking for unfamiliar, uninitiated faces inside.

The conference itself faded into insignificance, really. It was boring, very boring. Seven American and Canadian sites were hooked up with a Webcast to listen to two senior women not talk about what they're not doing about avian flu. I got to ask one question, which they didn't answer, and I wasn't allowed to ask any more.

If I understood it - and I was sleeping through the really boring parts, which is why I brought my tape recorder - the US and Canada aren't doing anything collaboratively about bird flu at all. Not unless you count setting up an enormous number of "working groups" and "expert panels." Oh, and unlike the 12 Asian nations that agreed to share a stockpile of antiviral medications the previous week, in North America it's everyone for themselves. Although that may change after their next meeting in Mexico in September, in the meantime there will be no sharing here, except of borders. Mind you, after the recent NAFTA squabbles over softwood lumber, perhaps it isn't that surprising. On this continent our mothers are wrong: just because you're the biggest, you don't have to share.

Sally Murray

Editorial Fellow

CMAJ 